\title{
The cultural politics of climate branding: Project Sunlight, the biopolitics of climate care and the socialisation of the everyday sustainable consumption practices of citizens-consumers
}

Article

Accepted Version

Doyle, J., Farrell, N. and Goodman, M. K. ORCID: https://orcid.org/0000-0003-4861-029X (2020) The cultural politics of climate branding: Project Sunlight, the biopolitics of climate care and the socialisation of the everyday sustainable consumption practices of citizens-consumers. Climatic Change, 163. pp. 117-133. ISSN 1573-1480 doi: https://doi.org/10.1007/s10584-019-02487-6 Available at https://centaur.reading.ac.uk/85045/

It is advisable to refer to the publisher's version if you intend to cite from the work. See Guidance on citing.

To link to this article DOI: http://dx.doi.org/10.1007/s10584-019-02487-6

Publisher: Springer

All outputs in CentAUR are protected by Intellectual Property Rights law, including copyright law. Copyright and IPR is retained by the creators or other copyright holders. Terms and conditions for use of this material are defined in 
the End User Agreement.

www.reading.ac.uk/centaur

\section{CentAUR}

Central Archive at the University of Reading

Reading's research outputs online 


\title{
The Cultural Politics of Climate Branding: Project Sunlight, The Biopolitics Of Climate Care and The Socialisation of The Everyday Sustainable Consumption Practices of Citizens-Consumers
}

Paper as part of a special issue on the Practices of Everyday Climate Culture for Climatic Change coedited by Goodman, Doyle and Farrell

\begin{abstract}
Authors
Julie Doyle, Centre for Research in Spatial, Environmental and Cultural Politics (SECP), University of Brighton
\end{abstract}

Nathan Farrell, Faculty of Media \& Communication, Bournemouth University

Michael K. Goodman, Department of Geography and Environmental Science, School of Archaeology, Geography and Environmental Science, University of Reading

Centre for Research in Spatial, Environmental and Cultural Politics (SECP), University of Brighton

Centre for Space, Place and Society (CSPS), Wageningen University, Netherlands

\section{abstract}

Many corporations are now in the business of bringing climate change 'home' in the everyday products that those, in much of the Minority world, can purchase and use, providing opportunities for consumers to literally and figuratively 'buy in' to climate mitigation. Yet, what are the implications of this form of highly-commoditised, corporate-led, consumer-focused climate branding? In the spaces and practices of the everyday, how and in what ways are corporations framing and socialising responses to climate change and global environmental and social issues? This paper explores these questions through a critical discourse analysis of Unilever's 'Sustainable Living Plan' (2010) and its 'Project Sunlight' campaign (2010-2016). Situating Unilever's sustainability agenda as indicative of the contemporary climate politics of the corporate sector, that also represents a pivotal moment in the cultural politics of climate change, we critically interrogate Unilever's mobilization of the affective and emotional registers of everyday life and human relations in its model of sustainable living. Specifically, we focus on the ways that Unilever encourages acts of branded consumption as a form of-what we call here-climate care, by invoking normative discourses of gender and family through a form of biopolitics, and, at a larger scale, how the corporation is shaping how particular forms of climate capitalism are socialised, normalised and practiced. In doing so, we shift critical attention away from sustainable business analyses of Unilever onto the unexplored socio-cultural dimensions of Unilever's sustainability model. We argue that Unilever's socialisation of climate branding and care works to depoliticise climate change actions and actors through a biopolitics that creates a false veneer of democratisation in the form of consumer choice, thereby curtailing more progressive societal action on climate change.

\section{Introduction}

A core debate amongst activists and academics within the cultural politics of climate change (e.g. Anderson 2011; Boykoff 2011; Boykoff and Goodman, 2009; Boykoff et al. 2009; Boykoff et al. 2015; Doyle, 2011a; Doyle et al. 2017) is how to make climate change more relevant and actionable at the everyday scale. Research has previously explored how news coverage develops readers' salience (O'Neill et al. 2103) and how icons like florescent lightbulbs and polar bears (Slocum 2004; Manzo $2010 a, b)$ help bring climate change "home" to people's ordinary lives. In parallel to their social 
responsibility commitments, many corporations are now in the business of bringing climate change home in the everyday products that those, in much of the Minority world, can purchase and use. From the lower carbon footprints of meat substitutes (Stevens et al. 2018), to carbon emissions reduction certification on household commodities (Ormond and Goodman 2015), corporations large and small are providing numerous everyday practices for consumers to literally and figuratively 'buy in' to climate mitigation. Yet, what are the implications of this form of highly-commoditised, corporate-led, consumer-focused climate branding? How are key corporate entities, as self-declared and self-responsibilised experts, defining the problems and solutions to climate issues? Thus, in the spaces and practices of the everyday, how and in what ways are corporations framing and socialising responses to climate change and global environmental and social issues? This paper explores these questions through a critical analysis of Unilever's 'Sustainable Living Plan', which was launched in 2010 and continued through its 'Project Sunlight' campaign until 2016.

Unilever is one of the world's largest consumer products corporations, with an annual turn-over of $€ 50.9$ billion and operating in over 190 countries (Unilever 2019). Originally a British soap manufacturer and seller in the late 1800s, the company was founded by the Lever brothers and combined colonialist market philosophies (McClintock 1995), philanthropic idealism, and a healthrelated social mission to produce and market its first ever commodity: Sunlight soap. Alongside its Sunlight factory on the Wirral, near Liverpool (UK), a village to house the factory workers was built in 1888. Named Port Sunlight, the Lever company thus both ensured, and pioneered, the incorporation of commodity production and worker's social welfare through branding. More recently, Unilever has been positioned "as the most dominant private sector leader" in sustainability (GlobeScanSustainability 2018, 4). Central to this is Unilever's commitment to putting "sustainability at the heart of our business model...to demonstrate how our approach contributes to a virtuous circle of growth: the more our products meet social needs and help people live sustainably, the more popular our brands become and the more we grow" (Unilever 2013a, 13). Thus, as the "effects of climate change ... becom[e] daily more evident", Unilever is ostensibly "setting...a new purpose" of "sustainable growth" (Unilever 2010, 3-4) through an ambitious commitment to "double our sales" and "halve the environmental footprint of the making and use of our products" by reducing "GHGs by $50-85 \%$ by 2050 " (Unilever 2010,3). Bypassing governmental regulation and action on sustainability, as "[g]overnments alone cannot provide solutions, so business and the public also have to rise to the challenge" (Unilever 2013a, 4), Unilever articulates itself, and its consumers' "everyday actions" (Unilever 2010,3), as the driving force confronting climate change. ${ }^{1}$

Given its unique position as a global corporate sustainability leader, in this paper we focus on Unilever's 'Sustainable Living Plan' and 'Project Sunlight' public engagement campaigns as representative of the contemporary climate politics and actions of the corporate sector and a pivotal moment in the cultural politics of climate change. We critically interrogate Unilever's mobilization of the affective and emotional registers of everyday life and human relations, identified by social scientists and media scholars as necessary modes of climate engagement (e.g. Lorenzoni et al. 2007; Leiserowitz 2006). Specifically, we focus on the ways that Unilever encourages acts of branded consumption as a form of-what we call here-climate care and, at a larger scale, how the corporation is shaping how particular forms of climate capitalism are socialised, normalised and practiced across the planet. In doing so, we shift critical attention away from existing sustainable business analyses of Unilever (Murphy and Murphy 2018), onto the unexplored socio-cultural dimensions of Unilever's sustainability model. We focus specifically on the discourses that shape Unilever's own positioning as a global sustainability/climate leader, its engagement with consumers through everyday emotions and branded actions, and the broader implications of this for

\footnotetext{
${ }^{1}$ While not a formal part of our analysis in this paper, Unilever's 2018 annual report (Unilever, 2019)-entitled 'Making Sustainable Living Commonplace' - further cements everyday and ordinary practices as the spaces of sustainability action tied to Unilever's brands and corporate ideology.
} 
progressive societal action on climate change.

Our analysis is situated within debates surrounding Corporate Social Responsibility (CSR) and social science research on the cultural politics of climate change, specifically how emotion and affect matter in climate discourses. We explain our methodology of multimodal discourse analysis of Unilever's campaign documents, online presence and Youtube videos before presenting our critical assessment of Unilever's 'Sustainable Living Plan' and 'Project Sunlight' campaign. First, we analyse the actors authorised by Unilever to act; here Unilever has nominated itself as an 'expert' of sorts on climate change and how responses should be practiced. Families-particularly, heteronormative families-figure heavily in Unilever's framing of actors, as do children and mothers, in a manner that privatises, individualises, but also family-ises the response to climate change through the use and purchase of Unilever's products. Second, we explore where and how action should take place. Action is, following Unilever's arguments, restricted to the choice and purchase of their green and socially conscious products, as well as through the actions of the company to lower its footprint, all supported by further purchases. These actions are couched in terms of care and emotion in Unilever's form of everyday climate care: that of families for the planet, mothers for their children, children for their parents, and of the planet. We conclude by analysing how Unilever's socialisation of climate branding and care work to depoliticise climate change actions and actors through a biopolitics that creates a false veneer of democratisation in the form of consumer choice.

\section{Conscience capitalism, climate capitalism and the carbon economy}

If read as a form of CSR, then Unilever's 'Sustainable Living Plan' is hardly unique. CSR is a commonly used term to describe "business firms contributing in a positive way to society by going beyond a narrow focus on profit maximization" (McWilliams 2014, 1). These practices are guided by the belief "that companies have a social role alongside their commercial one" (Cadbury 2006, 6). This role, Werther and Chandler $(2011,5)$ explain, is pursued "in addition to profit maximization". This suggests that CSR can be an external add-on, separate from, and in some instances peripheral to, the profit-seeking motive of the corporation. For example, through Unilever's partnership with UNICEF, it makes a donation to the NGO to aid the development of sanitation in the developing world, based on the sale of specific units of Domestos, a Unilever brand of domestic cleaning products. This type of "outsourced CSR" (Suliman et al. 2017) does not necessarily encroach on the fundamentals of Unilever's business model or production processes.

Taken as a whole, however, Unilever's 'Sustainable Living Plan' is more sophisticated. Rather than being a separate add-on to the objective of profit maximization, Unilever's sustainability goals are embedded directly within its very business model. This aspect of Unilever's 'Sustainable Living Plan' aligns the project with a set of political economic discourses that move beyond CSR and posit a greater social role for the corporate entity by positioning it as a key social and environmental actor. Described as "conscience capitalism" - an umbrella term for a range of loosely aligned discourses (Bishop and Green 2008) - these initiatives refer to a set of management theories and policy programmes that problematise the distinction between the profit-seeking motive of the corporation and their stated social and environmental responsibilities (Farrell 2015).

Conscience capitalists seek to transform business by incorporating ethics into the fundamentals of business practice. However, in making their case for this transformation, conscience capitalism's proponents rely on a traditional business case: it is good for business to be ethical, and being ethical increases profits because companies can "do well by doing good". Importantly, businesses that appear ethical may acquire a competitive advantage over rivals (Jones 2011). As such, the altruistic appearance of conscience capitalism is thrown into sharp relief because the calls for its adoption are frequently predicated on self-interest (Kotler and Lee 2009, 14-15). 
Conscience capitalism is rationalised by its proponents as ensuring the long-term sustainability of the corporate capitalist system. This is because considering the Earth as an infinite resource is clearly unsustainable. In addition, sustainability offers new areas for economic expansion as it prompts the development of new markets in sustainable technologies and 'green' goods. In order for sustainability to provide new arenas for capitalist expansion the natural world needs to be reconsidered as something that can be made to service but also fundamentally maintain corporate capitalism as a system. This is reflected in Hawken et al's (1999) concept of 'natural capital' in which they consider natural resources as something that fuels the greater economic whole. Corporate capitalism becomes more sustainable by commodifying the environment to subsume it into the economy, creating new markets through which this can happen. Thus, by ignoring the role played by industrial capitalism in the creation of many environmental problems, conservation and sustainability are considered "the White Collar's Burden" and, thus, something that businesses will have to solve. This is because, they argue, governments and NGOs have consistently failed to determine realistic and working solutions to the world's major problems (Strong 2009).

Delegitimising the role of government is a frequent part of this approach to business ethics, and it is common to find arguments that charities only maintain the status quo of world poverty (Frances 2008), or that governments are too inefficient and unadaptable to be able to solve catastrophic environmental problems (Bornstein and Davis 2011). In undermining the position of the state in this regard, corporations like Unilever can construct the business sector as not only a responsible global citizen but the only remaining international institution with the reach and assets to tackle climate change. This helps to stave off the government-led initiatives to tackle the environmental destruction that might hinder capitalist expansion - namely, regulation - and also to reconfigure the architecture of transitions towards sustainability in ways that profit the corporate sector.

Unilever, by its efforts to ameliorate climate change through conscience capitalism, is part of what has been called the "carbon economy". Critical work by Boyd et al (2011), Goodman and Boyd (2011) and Lohmann (2006) has explored how neo-liberal market-based mechanisms have been developed and 'naturalized' (Boykoff and Randalls 2009) to mitigate the effects of but also reduce further carbon emissions. These market-focused tools include such things as "flexible mechanisms (Clean Development Mechanism, Joint Implementation, International Emissions Trading) in the compliance market [and] carbon offsets in the voluntary market" (Boykoff and Randalls 2009, 2299) as well as carbon taxes and other forms of pricing carbon emissions, mitigation and resilience (Newell and Paterson 2010; Bohm et al. 2012). For Boykoff and Randalls $(2009,2301)$ carbon economies "extend far beyond the formal carbon markets. They suggest a reorganisation of economic principles to take into account carbon emissions from the product lifecycle, consumer behaviours or those sequestered in a forest used as an offset". More recent work has begun to account for these reorganisations through analyses of the politics of corporate carbon footprinting (Friedberg 2014) and the associated creation of third-party carbon emissions labelling (Ormond 2015).

Through our analysis of Unilever's 'Sustainable Living Plan' and 'Project Sunlight' campaigns, we argue that Unilever has opened up a new "front" in the carbon economy focused specifically on the association of the Unilever corporation and its branded commodities with the reduction of carbon emissions, support of progressive environmental causes and the development of resilience in communities. We call this new aspect of the carbon economy climate branding. What Bumpus and Livermann (2008) call "accumulation by decarbonisation" is here done through the repositioning of Unilever's corporate brand in the 'Sustainable Living Plan' and 'Project Sunlight' as a corporation in the business of caring about climate change. Before, moving onto the analysis to show how this repositioning is done and its implications, we situate Unilever's campaigns in the context of recent research into the cultural politics of climate change that prioritises the everyday as an effective emotional space for climate action and engagement, a prioritisation that Unilever makes through its branded commodities. 


\section{Caring for climate in the emotional spaces of the everyday}

Climate communication scholars and practitioners argue that climate change problems and solutions need to be made more culturally salient and actionable. Providing citizens with data and information about climate impacts often doesn't do enough to either shift beliefs or spur action. Rather, climate change requires understanding how cultural values and world beliefs - and their mediation (Doyle 2011a) - shape people's engagements (Wang et al. 2018). In the context of NGO campaigning, this shift can be illustrated through a recent focus upon care as an affective register for climate campaigning. Indeed, for Lorenzoni et al. $(2007,446)$ in addition to cognition and behavioural aspects, affect is one of the core components of the behavioural ecologies of a personal connection to climate change issues. For example, Climate Coalition's 'Show the Love' campaign seeks to create affective relations with "many of the things we love and cherish" that are being negatively impacted by climate change, in order to inspire behaviour change (Climate Coalition 2016).

This focus upon emotion is indicative of a broader affective turn in contemporary media culture and politics, with the rise of celebrity culture and the increasing role of celebrities as 'affective translation devices' who emote about climate change for the benefit of public understanding and engagement, and to elicit care about/for climate change (Doyle et al. 2017, 19; see also Boykoff and Goodman 2009). This focus upon emotion can be used to both harness and challenge cultural values:

Researchers and practitioners are increasingly calling for more localized, emotional/affective, and participatory modes of communication that more clearly link to, as well as challenge, people's existing social values and identity in order to make climate change understood and felt at the level of the everyday (Doyle et al. 2017, 13).

Hope, in particular, is important for motivating audiences and the public to engage with the environment and pro-environmental behaviours (Ojala 2012; Nabi et al. 2018). In essence, 'the moves to [develop] emotional registers' (Doyle et al. 2017, 18; see also Moser 2007) in climate change communications designed for behaviour change have the potential to make climate more salient in the face of data and scientific overload, knowledge/action gaps and funded dis-information campaigns. In the context of Unilever's 'Sustainable Living Plan' and 'Project Sunlight', the deployment of affect and emotion are, in our critical opinion, used cynically to not just sell more Unilever products but, in effect, also commoditise, individualise and family-ise care for the climate. As we will show, climate care through everyday purchases of Unilever's brands is simply another 'good' for sale through the processes of climate branding.

\section{Methodology}

This paper undertakes a multimodal discourse analysis of Unilever's 'Sustainable Living Plan' (2010) and its 'Project Sunlight' campaign (2013a, 2013b, 2013c). A 24-page report, the 'Sustainable Living Plan' launched Unilever's ambitious plan to double its sales while reducing GHG emissions. As part of Unilever's consumer engagement strategy, the 'Project Sunlight' campaign deploys slick marketing across a number of media platforms, including a website, advertising films, social media feeds and press releases. Whilst the social media feeds and press releases produced by Unilever inform the broader background material to our paper, the following texts are more specifically analysed in this paper: the 'Project Sunlight: Inspiring Sustainable Living' report (Unilever 2013a); the accompanying 'Acts of Sunlight' website; and a public engagement film, Why Bring a Child into This World?' (Unilever 2013b), that accompanied the launch of the 'Project Sunlight' campaign.

We employ multimodal discourse analysis to critically analyze-from our situated and contextualized perspectives - the social construction of meaning through written and visual texts produced by Unilever. Multimodal discourse analysis (Kress and Van Leeuwen 2001) analyses the construction of social meaning through visual and textual language, and is thus an appropriate method for the analysis of texts that incorporate both written and visual modes. Our approach to the critical analysis 
of visual and written texts also draws upon existing visual discourse analyses of climate change communication (Hansen and Machin 2008; Doyle 1997, 2011a; O'Neill et. al. 2013). As a fundamental aspect of discourse analysis, the language of specific texts is examined in relation to wider sociopolitical discourses and contexts (Fairclough 1995). Discourses represent particular values or beliefs, which in turn shape social life and social relations. Discourses are practices that are shaped by their production (for example, a corporate institution) and their reception (by the audience). Discourse analysis identifies what and how cultural values and power relations are communicated through language, with an attention to how discourses (re)produce social life and create a particular construction of social reality. Our analysis of Unilever texts examines word choice, narrative and lexical structure, visual signs, social actors and their specific actions, facial expression, body language, props, and music, to explore how Unilever discursively positions itself as a climate actor in the broader field of climate change politics and climate action. We examine how these discourses both position and invite consumers to take action and through what means, and specifically how emotion, care and the everyday are utilized to situate Unilever as taking action through climate care and climate branding

\section{Sustainable capitalism, 'family-isation' and capitalising on the climate}

For Unilever's sustainability ambitions to appear credible, key stakeholders in the climate movement, namely governments, the corporate sector and the public, are reconfigured. In its 'Project Sunlight: Inspiring Sustainable Living' report (Unilever 2013a), governments, institutions of the state, and supranational organisations are represented in ways that undermine their climate leadership: "[g]overnments have so far failed to introduce global agreements to address these growing resource demands or curb climate change" (3). In Unilever's opinion, supranational organisations fair little better due to the continued lack of progress of the UN Framework Convention on Climate Change. Undermining any perceived government monopoly of climate change management - "government alone cannot provide solutions" (4) - opens a space for other leadership sites. Unilever focuses upon "business and the public" who, in distinction from state and supranational organisations, "have to rise to the challenge" (3). Accordingly, businesses like Unilever are responsibilized as a climate actor due to governmental inadequacy.

Unilever's representational positioning of these three climate change stakeholders shares precedents within the conscience capitalism literature. Unilever contends that it has "a responsibility to take a leadership role in co-creating a world where everyone can live well and within the natural limits of our planet" (3) because it is "a global company whose products are used over two billion times a day in over half the households on the planet" (Unilever 2013a, 4). The commercial success that Unilever enjoys thus legitimises its leadership position in climate change mitigation. To sustain this proposition, the concept of sustainability is reconfigured as something that happens within a market system. Creating sustainable behaviour change is an expertise claimed by Unilever, developed over "decades of research and insights by behaviour change experts inside and outside of the company" (Unilever 2013a, 4) from which Unilever has devised whole "behaviour change programmes" to transform consumer habits. Capitalist value and profit generation is tied directly to climate mitigation and climate care by Unilever, its brands and its consumers. ${ }^{2}$ Catastrophic climate change is not the result of capitalist production and slow progress towards climate solutions are not the influence of actions by specific agents with particular political and economic agendas.

This capitalist-utopian view of sustainability is evident in Unilever's discursive positioning of the public, who might want to act but need to be shown how (Unilever 2013a, 5). Representing the "public" as interchangeable with "the consumer", Unilever positions these "citizen-consumers" as

\footnotetext{
2 The contradictions embedded in these notions of sustainability and capitalist growth have been the subject of ecological Marxism (e.g. O'Conner, 1998) and more recent work on the paradoxical concept of 'green growth' at the centre of international environmental governance (e.g. Hickel and Kallis 2019)
} 
possessing the environmental duties of a responsible citizen who mobilises through consumer practices. This iteration of the public as citizen-consumer is at the core of Unilever's vision of sustainability, underpinned by a representation of the public as self-interested individuals. For example, in attempting to discursively reframe the relationship between the public and climate change to make it more salient, Unilever positions the individual as living in what it calls "my world", a world circumscribed by ordinary everyday experiences - namely, home and family relationships. Far beyond "my world" is "the world", where global scale issues such as climate change or the distant suffering of others occur. Unilever states that, "[f]or most people [climate change] is an issue that relates to 'the world' rather than 'my world'".

Thus, as climate communication scholars argue for more localised and affective climate engagements, Unilever explicitly addresses this through the discursive repositioning of climate change as part of "the world" that requires refiguring within a "my world" mindset (Unilever 2013a, 6). However, this is not undertaken to create solidarity between people, or to elicit specific national, communal or historical responsibility for climate mitigation in the Minority world. Rather individuals are encouraged to see sustainable living in self-interested ways to their own benefit and that, very importantly, of their family. Individuals and their families are thus represented as the primary agents of sustainability transition, reminiscent of the oft-quoted mantra of Thatcherism: there is no such thing as society, there are only individuals and, now, families. Consequently, Unilever identifies selfinterest as a primary 'motivator' of sustainability, in the form of "personal and family health, wanting to preserve the world for grandchildren and future generations" (Unilever 2013a, 6). Transformational change is discursively positioned within the domestic sphere, with public spaces in which political protest might occur, and public institutions of formal politics, relegated to secondary positions. Unilever positions itself as a "bridge" between "my world" and "the world" of climate change through its consumer products. How it does this is the focus of the next section.

\section{Welcome to 'my world' as everyday sustainability}

Launched in conjunction with the 'Project Sunlight: Inspiring Sustainable Living' report, the 'Project Sunlight' public engagement campaign sought to "motivate millions of people to adopt more sustainable lifestyles' and 'make sustainable living desirable and achievable" (Unilever 2013b). 'Project Sunlight' was largely housed on the now defunct Unilever website, brightfuture.unilever.co.uk, which served as an "online hub" that brought "together the social mission stories of Unilever's brands across the world, and invite[d] consumers to get involved in doing small things which help their own families, others around the world and the planet" (Unilever 2013b). Essentially, this was a platform that digitally catalogued promotional stories about Unilever's ethical activities, and invited consumers to support Unilever's work through specific consumer practices. Under titles such as "Brands with a Purpose", "Climate Action", "Sunlight Activities", and "See the Possibilities", the website's content largely announced new campaigns, reported the successes of existing campaigns, interviewed partner organisations or Unilever personnel, or provided general commentaries, from the corporation's perspective, of environmental and social issues.

It is important to note the centrality of the word 'sunlight' as a specific form of climate branding that draws upon the socio-historical and philanthropic origins of Unilever as a company, and signals the need for current corporate and consumer optimism in addressing climate change through further commodity consumption. Sunlight directly references the historical origins of Unilever - then known as Lever Brothers - as a branded producer of Sunlight soap in the late $19^{\text {th }}$ century, whose mission was to "to make cleanliness commonplace" (Unilever 2018). Whilst the racialising imperative of "cleanliness" has been explored (McClintock 1995), the philanthropic ideals of the Lever Brothers also puts notions of cleanliness into practice through the building of houses with bathrooms for factory workers. Levers' notion of "prosperity sharing" was not to share profits with their workers, but to provide "them with decent and affordable houses...intended to inspire loyalty and 
commitment" (Port Sunlight 2018). Commodity production, and the Sunlight brand, was thus embedded within the everyday work and leisure practices of its workers, who produced, consumed and lived the Sunlight brand. Project Sunlight evokes this philanthropic and commodity ideal, and synthesizes it with more abstract notions, or feelings, of hope through reference to sunlight, brightness and futures. Similar to BP's use of the sunburst logo in 2001 to rebrand its corporate practices as sustainable (Doyle 2011b), Unilever uses the word "sunlight" to evoke positive change in the specific context of climate change. In doing so, it puts into discursive practice the feeling of hope as a motivating factor for climate action, through commodity consumption, of specifically Unilever products and notions of social good that they are meant to invoke.

The 'Project Sunlight' website works as an interface between producer and consumer in the promotion of branded climate actions in the everyday, and does so by combining environmental with social issues. In September 2016, prior to its removal, the 'Project Sunlight' website housed 84 stories dealing with a range of issues including climate change and sustainability, sanitation, food waste and food poverty. Fifty-eight of these stories (69\%) made specific reference to Unilever products. In total, there were 118 references to Unilever products across the 84 stories, demonstrating the branding potential of 'Project Sunlight' as it embedded Unilever products into discussions of climate and sustainability. The links between Unilever products and broader issues of climate change are often tangential, at best. For example, a story about the Unilever brand, Knorr, largely centred on an interview with a Unilever employee:

Every parent wants their family to enjoy mouth-watering meals made from healthy, natural ingredients, but getting the balance between simple and nutritious can be tricky.

It's a challenge that Knorr chef Einav Gefen is all too familiar with [...] She's worked with Knorr for years, developing products and recipe ideas that make mealtimes easier for families all over the world, including her own [...]

But Einav doesn't just believe in tasty, convenient cooking; she's equally passionate about Knorr's sustainability mission and supports its commitment that $100 \%$ of their agricultural raw materials will be sustainably sourced by 2020 (Unliever n.d., our emphasis).

The headline for this story predominantly concerns the aesthetic qualities of Knorr produce and their association with particular iterations of domesticity, the sustainable qualities of the product being an add-on.

The consumer-citizen public, here reformulated through domestic roles, are encouraged to act sustainably through the consumption of Unilever products. Through various "acts of sunlight" consumer-citizens can further engage with climate change and sustainability by recycling or using leftover food; engaging with family and community in Unilever-inclusive events such as parties catered with Unilever goods; raising awareness of 'Project Sunlight' by sharing content on social media; and signing Unilever-approved pledges and petitions. Through direct consumption of Unilever commodities and other branded actions, Unilever's form of climate capitalism internalises the processes, ideologies and ethics of conscience capitalism in its vision of sustainability.

With this, a particular biopolitics of care emerges as consumer-citizens can "savour the taste of Colman's English Mustard knowing it has been made with sustainably sourced English Mustard Seed." The body as a site of sustainability action establishes an important relationship between Unilever's proposed "my world" of the domestic sphere, populated by Unilever brands and commodities, and the external world of climate change, that Unilever (as experts) are operating responsibly within and for. This focus upon a body politics of the family as the locus of everyday climate action and responsibility is a key discursive practice of Unilever's 'Sustainable Living Plan', 
which finds more explicit articulation in its 4-minute public engagement film, 'Why bring a child into this world?' (Unilever 2013b), that accompanied the launch of the 'Project Sunlight' website and report. The next section explores this film in more detail, demonstrating how the idealised body/figure of the mother and child is situated at the centre of Unilever's sustainability vision to embed and embody climate capitalism through the normative ideologies of gender, family and heterosexuality.

\section{Acts of family-ised and global care as gendered visions of climate futures}

Unilever states its aim is to make sustainable living "a new social norm" (Unilever 2013a, 9). The film, 'Why bring a child into this world?' (Unilever 2013b), is an important part of Unilever's attempts to make sustainability "intrinsic" rather than "extrinsic", through a focus upon family and home. Set around a series of interviews with 11 expectant heterosexual couples ( 5 white, 5 asian, 1 black; no differently raced couples), from across the world, the film shows each couple sharing their fears and hopes about their unborn child. Moving beyond the polar bear, two visual tropes, or icons, are deployed in the film to communicate care for the environment, world and the future: the visibly pregnant female body, and the figure of the (imminent/present/future) child. The film opens with the camera focusing in upon the pregnant female body, with close ups of the women stroking their swollen bellies. Next to the women sit the men, some with protective arms around the women, others helping their pregnant partner to sit down safely. The women are verbally silent throughout, their visibly pregnant bodies acting as a synecdochal sign of the futures discussed by the men. The men speak on behalf of the women and their imminent child: of the joy, the realisation that they are "someone else's protector", and their worries "for the baby". Men thus signify as protectors of the female body and unborn child, while the women are reduced to their pregnant bodily form, acting as a conduit for male hopes and fears that are recuperated through the female body and its offspring.

Occupying a dominant verbal position, the men also drive the filmic narrative forward, providing the emotional hook and shift in tone from despair to hope. Each couple is made to watch a montage of images of war, poverty and environmental destruction, against which the question "why bring a child into the world?" is juxtaposed, the implied answer being that it would be selfish to do so. The gravel toned male voiceover then shifts the emotional direction from one of fear and despair to one of hope through an invocation to "something that is already happening today": more food being grown "through a revolutionary method: care", new technologies for clean water, prevention of illness "by simple everyday products", against which children are visually depicted as both playing and learning together. The voice over exhorts,

Bring your child into this world [close up of white baby]. There has never been a better time to create a better future for everyone on the planet, for those yet to come [close up of bare pregnant belly being stroked] (our emphasis).

This shift in tone and imagery is accompanied by close ups of the couples laughing and crying. Men visibly cry, apparently undermining gendered expectations of feminised care. Yet, it is the men who verbally dominate throughout, creating both the ideological and affective parameters through which sustainable living ought and should be done.

The affective and ideological parameters of sustainable lives are exemplified in two narrative moments, where procreation and childbirth are ideologically naturalized as the appropriate - and only - response to sustainability, despite the impacts of population growth on resource availability and climate change. Utilising the narrative of "compulsory sexual reproduction" (Munro 2017, 238), one (black) man states, "sometimes people use the environment and the world as an excuse to say it is not the right place to bring up a child" (our emphasis). The hegemonic position here is that sexual reproduction (visualized by the pregnant female body) is a choice for women that would be selfish/unnatural not to take. Deeply sexist, this positions women as the naturalised bearers of future generations, and saviours of an imagined sustainable future - without recourse to any 
concrete actions to mitigate climate change. Furthermore, this articulation of compulsory motherhood is simultaneously superseded by the verbal articulations of men. One (white) man states, "The world needs more good guys. I like to think our baby will be one of the good guys". The implication here is that the good guys (note the gendered male term) are white, middle class children who will become responsibilised (Unilever) consumers, like their parents. The juxtaposition of destructive images with those of babies as a means of generating both fear and hope fails to acknowledge the gendered, raced and classed power relations and the structural inequalities which contribute to war, famine, poverty and climate change. Instead, men's activities are recuperated through their women, who as mothers are called upon to "symbolically clean up the messes created by powerful men in the public sphere by devoting themselves to mothering and the 'endangered' domestic sphere" (Munro 2017, 234).

Future planetary narratives are imagined and situated by men through the bodies of pregnant women. While the woman's body is the sign of both anticipated and imminent futures, the unborn child is also central to this narrative. The use of idealized children/the child-signified in the film by the white baby - is an example of "reproductive futurism" (Edelman, in Munro 2017), where children are positioned as the hope for the future, while simultaneously inscribed by their own future reproductive capacities. For example, the voice over states: "by the time they [children] find the right person, our children will have better chances of meeting their great grandchildren than we ever did". As such, compulsory reproduction is prescribed as the legitimized act of sustainability: Children are thus both the catalyst for (in terms of expectant parents) and future progenitors/custodians (through their own future reproductive capacity) of sustainability. Both sets of interdependent discourses position women without agency; even the emotional labour of caring is taken over by men, who visibly cry.

Positioned as the affective motivator for adults' adoption of sustainable lifestyles, children bear the symbolic burden of these imagined future worlds. This responsibility is viewed by Unilever as part of children's 'natural sunny outlook on the world', which inspires adults to become more sustainable: a position that emerges from research undertaken by global marketing firm, Edelman Berland, to form Unilever's 'Project Sunlight White Paper' (Unilever 2013c, 7). Surveying 8,000 people - half parents, half children - in the UK, USA, India and Indonesia, parents were asked about changes in their lifestyle as a result of having their first child, while their children (aged 8-12 years) were asked about their feelings about the future and the environment. Although the children say they are very/fairly optimistic about the future, the acts of sustainability that are encouraged by this optimism are small actions, such as turning off lights, the tap and appliances, recycling, buying fair-trade products and washing laundry at lower temperatures, corresponding with those identified on the 'Project Sunlight' website. These individualised "small steps" actions have been criticised as a marketing strategy that do not lead to deeper behavioural changes (Crompton 2008). Unilever's use of the affective register of children's optimism to help inspire a prescribed set of sustainable actions thus naturalise those acts as able "to make the world a better place" (Unilever 2013c, 25).

While hope and optimism are being used here as a marketing tool, research with young people shows that this age group are naturally more optimistic about addressing climate change than teenagers, but that this optimism is a coping strategy linked to both de-emphasizing and distancing oneself from the threat (Ojala 2012). Significantly, as this age group have the least agency/ability to cope with negative emotions, then the kinds of pro-environmental strategies that are promoted have significant implications for the kinds of behaviours that are legitimised as sustainable. As such, Unilever's use of children as a way for adults to care about climate change and sustainability are highly problematic because they not only situate sustainability as a form of commoditised lifestyle action for adults, they also inscribe children within this discourse, failing to provide meaning-focused strategies for addressing climate change. Furthermore, by utilising deeply pernicious discourses of heterosexual reproduction to promote care for the climate/future, both women's and children's 
bodies are inscribed as the site of anticipated change, with Unilever providing the branded commodities through which material changes can take place.

\section{Discussion and conclusion: Socialising climate care, de-politicisation and climate democracy as climate branding}

Unilever, through its powerful 'Sustainable Living Plan' and 'Project Sunlight' campaigns and associated corporate re-alignment, has sought to frame society's responses to the climate crisis in terms of a climate branding that is built on the individualised and commodified care of citizenconsumers in the guise of fathers, mothers and children. In Unilever's scenario, responsibilised individual citizen-consumers are family-oriented, family-focused and concerned with the continuing viability of not just their own families in their 'my world' but, by proxy, "the world" being impacted by climate change. The everyday choice for Unilever's commodities is, thus, a biopolitical choice (Goodman 2013b; Goodman et al. 2017; Sexton 2016, 2018; see also Mansfield 2012; and BobrowStrain 2008): by choosing and using Unilever's brands, one is literally working to ensure the continued survival not only of the planet, but also of one's own life and that of one's own existing and future family. Here, the framing of climate change responses slips the bounds of the previous locations and authorised voices in the form of the media, climate scientists and climate activists. Instead, framing is done here by one of the largest corporations on the planet, through its sustainability plans and commitments, but, most importantly, through the everyday commodities and branded actions, advertisement and marketing materials that materialise our everyday commitments to ourselves, our families and the climate changed world. Climate change mitigation is thus uniquely framed through the everyday products and goods we use as well as the everyday relations we have as family members.

Unilever's framing also ensures their own continued economic and market growth as one of the world's largest consumer products corporation, but one who will save the world, societies and even corporations from themselves. This framing, thus, socialises a distinct politics of climate change and its mitigation: corporate-led, commoditised climate branding is the "common sense" way to confront climate change and doing this has real world impacts on others, nature and the state of global ecologies. This biopolitics, from a critical perspective, works to give a false veneer of the democratisation of climate, in that we can vote with our money through the purchase of Unilever products and support of their economic bottom line through our everyday shopping choices and use of goods. In many ways, Unilever's framing and socialisation - of themselves as climate experts, of citizen-consumers and families as the figures of climate "redemption" and of the everyday purchase and use of their products is the solution to climate change-is an insidiously clever twist on the need to make climate change a salient, everyday and actionable issue with a distinct set of 'do-able' solutions. The ironies of the deployment of these discourses as the way to bring climate change home and the pathways that tie this directly to this form of climate branding should not be lost on critical scholars working on climate change communication.

Importantly, Unilever's climate biopolitics are created and articulated through emotional and affective registers of what we have called climate care. Care for oneself-but most importantly care for one's heteronormative family in the form of future children-is actualized into the care for the planet through the purchase of Unilever products. In this "emotional capitalism" (Illouz 2007), family relations of love, care and concern are commodified: these relationships and their expression are purchase-able through Unilever's goods at the very same time these affective relations are tied directly to that for the planet-all of which is embedded in the very everyday commodities that Unilever sells to us. Simultaneously, these same relations of love and care for our families and future children are politicised in suspect ways as affective actions for the climate. Put simply, Unilever's facilitation of climate care through the Sustainable Living Plan and Project Sunlight problematically hijack both the processes of climate salience and that of a caring, loving family in the service of 
corporate profit in ways that deepen and broaden the reach of the carbon economy and climate capitalism into the intimate relationships amongst mothers, fathers and children in deeply gendered, raced and classed ways.

We close with two related concerns. First, we feel that there is something morally objectionable about profiting off climate change and the deepening commodification of our affective relations within families. The more we materially consume (which too is very problematic), the more we love our families and children, the more we save the planet and the more we grow the bottom line of Unilever. Same too with the particularly heteronormative, raced and sexist imaginaries Unilever develops in framing our responses to climate change. These deeply disturbing discourses have not only embedded neoliberal rationalities within climate care and indeed, particular views of the family and relations between men, women and their children, but cement an emotional and affective transactionalisation in not just the carbon economy, but also into the everyday, private space of the home. The carbon economy, with the efforts of Unilever's Sustainable Living Plan and Project Sunlight is one that not only commodifies affect, care and emotion around the environment, but is fundamentally held together through these assemblages and the personal, familial and corporate actions that create and connect them in the spaces of the everyday. The ways these assemblages of everyday climate action and their framings create and maintain particularly raced, classed and gendered imaginaries of climate mitigation and sustainable societies must be more fully analysed by climate and social science scholars.

Second, our core concern is how the climate branding and climate care of the Sustainable Living Plan and Project Sunlight work to overtly de-politicise climate action through this consumptionist approach to climate problems. Privatisation and the commodification of climate care-and corporate profits-are emphasised with the much harder work of organising political change and structural transformation nowhere to be found. Indeed, there is an almost palpable delegitimisation of climate change as a social problem worthy of wider collective, public or government and regulatory action. This is highlighted in Unilever's specific discourse about the lack of governments' abilities to solve the climate problem and the specific space this opens up for their commodified brands of climate capitalism and climate care. And while there is something to the ways that these everyday consumerist responses to environmental and social problems might empower publics as a suite of actions people take to make the world a better place (e.g. Barnett et al. 2005, 2011), we sound a note of caution in this specific case of Unilever climate branding and its advocacy of ethical and sustainable consumption. To say nothing about concerns over who participates and who benefits and how, we are concerned about Unilever's economic, cultural and political influence to direct how societies and the public engage with, respond to and deal with the climate crisis. In addition, climate care through the pathways of climate branding and climate capitalism produces the appearance of democraticisation of responses to climate change and the ways and means by which societies can decide their environmental and social futures. This appearance of democraticisation through our (supposedly) empowered, everyday choices is, in reality, about maintaining and entrenching corporate power-and that specifically of Unilever-across the politicised terrain of climate politics and the survival of the planet. What is needed, indeed, required is the socialisation of novel social imaginaries, framings and narratives - as tied to novel, alternative political economies - that work for deeper and more equitable social and ecological change in the face of climate change. It is our hope that the critiques provided in this paper fundamentally question both climate branding and climate care as envisioned and materialised in Unilever's powerful imaginaries in efforts to reclaim them for more critical and justice-producing ends.

\section{Acknowledgements}

Many thanks to Alex Sexton, Filippo Menga and Hilary Geoghegan who read and commented on an earlier draft; their interventions have greatly improved the paper. Thanks also to the insightful and 
helpful comments from the reviewers and Max Boykoff as journal editor. Mike wishes to thank Avril Maddrell and his Human Geography Research Cluster colleagues for setting up the Stroud writing retreat funded by the School of Archaeology, Geography and Environmental Science at Reading where this paper had its very modest beginnings. Finally, many thanks for the engagement and comments on our original paper by the participants of the Practicing Everyday Climate Cultures workshop held at the University of Reading, September 2016.

\section{References}

Anderson, A., 2011. Sources, media, and modes of climate change communication: the role of celebrities. WIREs Climate Change 2 (4), 535-546.

Barnett, C., et al. (2005). "Consuming ethics: articulating the subjects and spaces of ethical consumption." Antipode 37: 23-45.

Barnett, C., Cloke, P., Clarke, N., Malpass, A. (2011). Globalizing Responsibility: the political rationalities of ethical consumption. Blackwell, London.

Bishop, Matthew and Green, Michael (2008) Philanthrocapitalism, A\&C Black: London.

Bobrow-Strain, A. (2008). White bread bio-politics: purity, health, and the triumph of industrial baking. Cultural Geographies, 15(1), 19-40.

Bornstein, David and Davis, Susan (2011) Social Entrepreneurship: What Everyone Needs to Know, Oxford University Press: New York.

Boyd, E., Boykoff, M., Newell, P. (2011). 'The "New" Carbon Economy: What's New?', Antipode 43 (3), 601-611.

Boykoff, M. (2011). Who Speaks for the Climate?: Making sense of reporting on Climate change. Routledge, London.

Boykoff, M., Randalls, S. (2009). 'Introduction: Theorizing the Carbon Economy', Environment and Planning A 41, 2299-2304.

Boykoff, M. T., \& Goodman, M. K. (2009). Conspicuous redemption? Reflections on the promises and perils of the "Celebritization" of climate change. Geoforum, 40(3), 395-406.

Boykoff, M., Goodman, M., Curtis, I. (2009). 'The Cultural Politics of Climate Change: Interactions in the Spaces of the Everyday', in: Boykoff, M. (Ed.), The Politics of Climate Change. Routledge, London, pp. 136-154.

Boykoff, M, McNatt, M and Goodman, M (2015) Communicating in the Anthropocene: the cultural politics of climate change news coverage around the world in Cox and Hansen, International Handbook of Environment and Communication

Bumpus, A., Liverman, D. (2008). 'Accumulation by decarbonisation and the governance of carbon offsets', Economic Geography 84 (2), 127-155.

Cadbury, Adrian (2006) 'Corporate social responsibility', Twenty-First Century Society, 1(1), 5-21

Climate Coalition (2016). Show the Love. https://www.theclimatecoalition.org/show-the-love/ Climate Outreach, 2018 
Crompton, T. (2008). Weathercocks and Signposts: The environment movement at a crossroads. (Godalming: WWF-UK).

Doyle, J. (2007). 'Picturing the Clima(c)tic: Greenpeace and the representational politics of climate change communication (1994-present)'. Science as Culture, Vol. 16, No. 2, June 2007, pp. 129-150.

Doyle, J. (2011a). Mediating Climate Change. Abingdon: Routledge

Doyle, J. (2011b). 'Where has all the oil gone? BP branding and the discursive elimination of climate change risk'. In Nick Heffernan and David Wragg (eds) Culture, Environment and Eco- Politics. Newcastle: Cambridge Scholars Press, pp. 200-225.

Doyle, J, Farrell, N. and Goodman, M. (2017). 'Celebrities and climate change' In Nisbet, M. (Ed.), The Oxford Encyclopedia of Climate Change Science. Oxford: Oxford University Press.

Fairclough, N. (1995). Critical discourse analysis: the critical study of language. London: Longman. Frances, Nic (2008) The End of Charity: Time for Social Enterprise, Allen \& Unwin: New South Wales GlobeScan-Sustainability (2018). GlobeScan-Sustainability Leaders Survey https://globescan.com/2018-sustainability-leaders-report/

Goodman, M. (2013b). 'iCare Capitalism?: The Biopolitics of Choice in a Neo-Liberal Economy of Hope', International Political Sociology 7, 103-105.

Goodman, M., Boyd, E. (2011). 'A social life for carbon?: commodification, markets and care special Issue', The Geographical Journal 177 (2).

Goodman, M. K., Johnston, J., \& Cairns, K. (2017). 'Food, media and space: The mediated biopolitics of eating', Geoforum, 84, 161-168.

Hansen, A. and Machin, D. (2008). 'Visually branding the environment: climate change as a marketing opportunity', Discourse Studies, 10(6): 777-794.

Hawken, P., Lovins, A. B. \& Lovins, L. H. (1999) Natural Capitalism: Creating the Next Industrial Revolution, Little, Brown and Company: Boston.

Hickel, J and Kallism, G. (2019): Is Green Growth Possible?, New Political Economy, https://doi.org/10.1080/13563467.2019.1598964

Illouz, E. (2007). Cold intimacies: the making of emotional capitalism. Polity Press, Cambridge.

Kotler, Philip and Lee, Nancy R. (2009). Up and Out of Poverty: The Social Marketing Solution, Pearson Education: New Jersey.

Kress, G. and Van Leeuwen, T. (2001) Multimodal Discourse Analysis. London: Arnold. istepe:

Leiserowitz, A. (2006). 'Climate change risk perception and policy preferences: The role of affect, imagery, and values', Climatic Change, 77(1-2), 45-72.

Lohmann, L. (2006). 'Carbon Trading: a critical conversation on climate change, privatisation and power', Development Dialogue 48 (September). 
Jones, D. (2012). Who Cares Wins, Harlow: Pearson Education.

Lorenzoni, I., Nicholson-Cole, S., \& Whitmarsh, L. (2007). 'Barriers perceived to engaging with climate change among the UK public and their policy implications', Global Environmental Change, 17(3-4), 445-459.

Mansfield, B. (2012). "Gendered biopolitics of public health: regulation and discipline in seafood consumption advisories." Environment and Planning D: Society and Space 30: 588-602.

McClintock, A. (1995). Imperial Leather: Race, Gender, and Sexuality in the Colonial Contest. London: Routledge.

McWilliams, Abagail (2014) 'Corporate Social Responsibility', in Cary L. Cooper [ed.] Wiley Encyclopaedia of Management. Hoboken, New Jersey: Wiley.

Manzo, K. (2010a). 'Beyond polar bears? Re-envisioning climate change', Meteorological Applications, 17(2), 196-208.

Manzo, K. (2010b). 'Imaging vulnerability: The iconography of climate change', Area, 42(1), 96-107.

Moser, S. C. (2007). 'More Bad News: the risk of negotiating emotional responses to climate change information'. In S. C. Moser \& L. Dilling (Eds.), Creating a Climate for Change: Communicating Climate Change and Facilitating Social Change (pp. 64-80). Cambridge University Press.

Munro, K. (2017). 'Hegemonic stories in environmental advocacy testimonials', Energy Research and Social Science, 31: 233-239.

Murphy, P. E. and Murphy, C. E. (2018). 'Sustainable Living: Unilever' in E. O'Higgins and L. Zsonai, Progressive Business Models: Creating Sustainable and Pro-Social Enterprise. Basingstoke: Palgrave Macmillan.

Nabi, R. L., Gustafson, A., \& Jensen, R. (2018). 'Framing Climate Change: Exploring the Role of Emotion in Generating Advocacy Behavior', Science Communication, 40(4), 442-468.

Newell, P., \& Paterson, M. (2010). Climate Capitalism. Cambridge: Cambridge University Press.

Ojala, M. (2012). 'Regulating worry, promoting hope: How do children, adolescents, and young people cope with climate change?', International Journal of Environmental and Science Education, 7(4): 537-561.

O'Neill, S., Boykoff, M., Day, S., Niemeyer, S. (2013). 'On the use of imagery for climate change engagement', Global Environmental Change 23, 413-421.

Ormond, J. (2015). 'New Regimes of Responsibilization: Practicing Product Carbon Footprinting in the New Carbon Economy', Economic Geography, 91(4): 425:448.

Ormond, J., \& Goodman, M. K. (2015). 'A new regime of carbon counting: The practices and politics of accounting for everyday carbon through CO2', Global Environmental Change, 34, 119-131.

Port Sunlight (2018). 'History and Heritage'. http://portsunlightvillage.com/about/history-andheritage/

Sexton, A. (2016). Alternative Proteins and the (Non) Stuff of "Meat." Gastronomica: The Journal of 
Critical Food Studies, (August).

Sexton, A. E. (2018). 'Eating for the post-Anthropocene: Alternative proteins and the biopolitics of edibility', Transactions of the Institute of British Geographers, 43: 586-600.

Slocum, R. (2004). 'Polar Bears and Energy-Efficient Lightbulbs: Strategies to Bring Climate Change Home', Environment and Planning D: Society and Space, 22(3): 413-438

Stephens, N., Di Silvio, L., Dunsford, I., Ellis, M., Glencross, A. \& Sexton, A. (2018). 'Bringing cultured meat to market: Technical, socio-political, and regulatory challenges in Cellular Agriculture, Trends in Food Science and Technology, 78, 222-233.

Strong, Michael (2009) Be the Solution: How Entrepreneurs and Conscious Capitalists can Solve All the World's Problems, John Wiley \& Sons: New Jersey.

Suliman, Abubakr, M. et al (2017) 'Corporate Social Responsibility: The Evolution, Theories, and Critics' in Agata Stachowicz-Stanusch [ed.] Corporate Social Performance: Reflecting on the Past and Investing in the Future, Information Age: Charlotte, NC, 15-32.

Werther, William B. and Chandler, David (2011). Strategic Corporate Social Responsibility: Stakeholders in a Global Environment (2nd Ed), Sage: California.

Unilever (2010). Sustainable Living Plan: Small Actions. Big Difference.

https://www.unilever.com/Images/unilever-sustainable-living-plan_tcm244-409855_en.pdf

Unilever (2013a). 'Project Sunlight: Inspiring Sustainable Living' Report.

https://www.unilever.com/Images/unilever-project-sunlight-inspiring-sustainable-livingreport_tcm244-417252_en.pdf

Unilever (2013b). 'Why bring a child into this world?' Video by Errol Morris.

Unilever (2013c). 'How Children Inspire Sustainable Living', White Paper prepared by Edelman Berland.

Unilever (2018). 'Our History'. https://www.unilever.co.uk/about/who-we-are/our-history/

Unilever (2019). 'Annual Report: Making Sustainable Living Commonplace'.

https://www.unilever.com/Images/unilever-annual-report-and-accounts-2018_tcm244-

534881_en.pdf

Wang, S., Leviston, Z., Hurlstone, M., Lawrence, C., \& Walker, I. (2018). Emotions predict policy support: Why it matters how people feel about climate change. Global Environmental Change, 50(August 2017), 25-40 